\title{
HUMOROUS POWER POINT: INTEGRASI HUMOR DALAM PEMBELAJARAN GENETIKA
}

\author{
${ }^{1}$ Sitti Saenab, ${ }^{2}$ Nurhayati dan ${ }^{3}$ Hamka, L \\ 1,2,3 Universitas Negeri Makassar, Jl. A. P. Pettarani \\ E-mail: sitti.saenab@unm.ac.id
}

\begin{abstract}
Abstrak: Penggunan media dalam pembelajaran merupakan salah satu cara untuk membuat materi ajar menjadi lebih menarik bagi siswa, akan tetapi jika tidak dikelola dengan baik maka tidak akan berfungsi sebagaimana mestinya, misalnya dalam hal penggunaan power point karena itu guru dituntut untuk lebih kreatif dalam memanfaatkan media pembelajaran. Penggunaan media power point dengan integrasi humor di dalamnya akan membuat siswa nyaman dan menjadikan proses belajar secara keseluruhan lebih menyenangkan. Tujuan penelitian ini adalah untuk mengembangkan media power point berbasis humor pada konsep genetika, penelitian ini merupakan penelitian pengembangan dengan menggunakan model pengembangan 4-D yang dikembangkan oleh $\mathrm{S}$. Thiagarajan, Dorothy S. Semmel, dan Melvyn I. Semmel. Model pengembangan 4D terdiri atas 4 tahap utama yaitu: Define (Pembatasan), Design (Perancangan), Develop (Pengembangan) dan Disseminate (Penyebaran). Hasil validasi media diperoleh bahwa media power point berbasis humor yang dikembangkan telah valid. Dari hasil validasi tersebut disimpulkan bahwa media power point berbasis humor yang dikembangkan layak untuk digunakan.
\end{abstract}

\section{Kata Kunci:Power Point, Strategi Humor, Genetika}

\section{HUMOROUS POWER POINT INTEGRATION HUMOR IN LEARNING GENETICS}

\begin{abstract}
The use of the media to learning is one of the ways to make teaching to deliver the material was makes itself more attractive to students, will but is otherwise not of managed that very well their torment shall not be able to continue functioning as well as it should, eg on the use of power point is the reason why the requiring teachers to be more creative in the harness of media. Media uses power point with the integration humor in it will be make a student to lose their comfortable and make the most powerful to the learning process as a whole more than mere fun. The purpose of this research is to develop a the media power point based humor to the concept of genetics, the research is of research development by the use of model of development 4-d which was developed by the $\mathrm{S}$. Thiagarajan, Dorothy S. Semmel, and Melvyn I. Semmel. Model of development 4d
\end{abstract}


consists of 4 of a primary stage pt pgn promised to supply: define (to limit the number of), including on the instrument types (particular in the design), develop (the development of), and disseminate (the spread of). The results of the matter of validating the media obtained that media is power point based humor that developed has been valid. From the results of the matter of validating entrusted the media power point based humor that developed worthy of to be used.

\section{Keywords: Power Point, Humor Strategy, Genetics}

Penggunaan media merupakan salah satu cara untuk membuat materi pelajaran yang membosankan menjadi lebih menarik bagi siswa. Bosan adalah penyakit yang amat berbahaya dalam pembelajaran. Jika perasaan bosan menyerang peserta didik, maka bisa dikatakan sebagian organ tubuhnya tidak produktif termasuk otak. Karena pada saat bosan otak tidak lagi dapat diajak kompromi untuk berfikir dan memproses informasi. Dan saat itulah proses pembelajaran yang diikuti oleh peserta didik menjadi sia-sia. Sebenarnya rasa bosan itu dapat diatasi dengan penggunaan media yang disertai selipan humor.

Sebagai alat pedagogis, humor dapat mengurangi kecemasan siswa, dan rasa canggung dalam kelas. Penerapan humor yang efektif dapat membantu guru untuk melibatkan siswa dalam pembelajaran dan bahkan meredakan tekanan atau stress selama ujian (McGrath, 2013). Planned humor adalah humor yang dapat dilakukan oleh semua guru dalam pembelajaran karena tidak mengharuskan guru menjadi seorang pencipta, perancang humor dan menguasai teknik humor yang baik. Planned humor hanya memerlukan sedikit kemampuan untuk memilih dan meramu humor yang diperoleh dari berbagai sumber dan dianggap bermanfaat untuk menciptakan keriangan dan kesenangan dalam belajar (Darmansyah, 2010). Jika seorang guru tidak merasa nyaman sebagai sumber humor maka guru dapat menggunakan konten-konten lain yang bernuansa humor dalam pengajaran. Guru dapat menggunakan media visual seperti gambar kartun, video lucu, dan juga mengarahkan siswa pada website-website humor. Berbagai jenis humor yang digabungkan dalam pembelajaran dianggap oleh siswa sebagai alat yang memfasilitasi membuat kesenangan dan kenyamanan dalam kelas (Wanzer, 2002). Konten-konten yang bernuansa humor tersebut dapat dipresentasikan dengan menggunakan power point. Tentunya guru sudah sangat familiar dengan media ini, sehingga tidak terdapat kesulitan dalam mengoperasikannya. Sejalan dengan hal tersebut maka penelitian ini bertujuan untuk mengembangkan media power point berbasis humor yang valid. 


\section{METODE PENELITIAN}

Penelitian ini termasuk penelitian pengembangan (development research) yang bertujuan mengembangan perangkat pembelajaran dan mengembangan instrumen secara simultan. Pada saat mengembangkan media pembelajaran, maka instrumen yang berkenaan dengan media pembelajaran juga dikembangkan. Jika dalam proses pengembangannya terdapat aspek-aspek yang direvisi pada media pembelajaran, maka akan dilakukan penyesuaian pada aspek-aspek instrumen.

\section{Pengembangan Media dan Instrumen}

Media pembelajaran yang dikembangkan dalam penelitian ini menggunakan model pengembangan 4-D yang dikembangkan oleh S. Thagarajan, Dorothy S. Semmel, dan Melvyn I. Semmel. Model pengembangan 4D terdiri atas 4 tahap utama yaitu: Define (Pembatasan), Design (Perancangan), Develop (Pengembangan) dan Disseminate (Penyebaran).

Langkah-langkah model pengembangan yang dikemukakan oleh S. Tharagajan dijelaskan sebagai berikut:

a. Tahap pendefinisian (define)

Tujuan tahap ini adalah menetapkan dan mendefinisikan syarat-syarat pembelajaran di awali dengan analisis tujuan dari batasan materi yang dikembangkan. Tahap ini meliputi 5 langkah pokok, yaitu: (a) Analisis ujung depan, (b) Analisis siswa, (c) Analisis tugas. (d) Analisis konsep, dan (e) Perumusan tujuan pembelajaran. Pada tahap ini akan dilakukan investigasi terhadap kondisi pembelajaran biologi di kelas yang digunakan oleh guru, kondisi yang dimaksud meliputi pendekatan yang digunakan oleh guru, tujuan pembelajaran yang direncanakan. Untuk mengembangkan media pembelajaran yang sesuai dengan kebutuhan tujuan yang ingin dicapai dalam penelitian ini, maka dilakukan investigasi dan identifikasi terhadap kondisi siswa, kondisi guru, tuntutan lingkungan terhadap pembelajaran biologi, dan kurikulum biologi yang berlaku. Kondisi-kondisi ini seluruhnya dikaitkan dengan kemungkinan pengembangan media pembelajaran berbasis humor pada kompetensi dasar mata pelajaran biologi di kelas XII. b. Tahap perancangan (Design).

Tujuan tahap ini adalah menyiapkan prototipe media pembelajaran. Pada tahap ini, dirancang pembelajaran yang konstruktivistik. Untuk keperluan pengumpulan data tentang media yang telah dibuat, maka dikembangkan pula instrumen yang akan digunakan untuk mengukurnya. Jenis instrument yang diperlukan adalah instrumen untuk mengukur kevalidan.

c. Tahap pengembangan (Develop)

Tujuan tahap ini adalah untuk menghasilkan media pembelajaran yang sudah direvisi berdasarkan masukan dari pakar. Tahap ini meliputi: (a) validasi media oleh para pakar diikuti dengan revisi, (b) simulasi yaitu kegiatan mengoperasionalkan media, dan 
(c) uji coba terbatas dengan siswa yang sesungguhnya. Hasil tahap (b) dan (c) digunakan sebagai dasar revisi.

d. Tahap penyebaran (Disseminate)

Pada tahap ini merupakan tahap penggunaan perangkat Prototipe Final yang telah dikembangkan pada skala yang lebih luas misalnya, di sekolah lain, oleh guru yang lain. Namun karena pertimbangan waktu, maka tahap penyebaran belum dilaksanakan dalam penelitian ini.

Sebagaimana telah dikemukakan dalam langkah pengembangan pembelajaran di atas, maka instrument yang dikembangkan dalam penelitian ini terdiri atas:

1) Lembar penilaian media pembelajaran berbasis humor yang terdiri dari aspek format, dan aspek konten.

2) Format validasi media dan instrumen. Validitas diselidiki dengan dengan menggunakan validitas teoritis melalui penilaian ahli dan praktisi. Untuk mendapatkan kevalidan perangkat dan instrument maka diperoleh dari ahli dan praktisi yang memvalidasi format, materi pembelajaran, instrumen, validasi keterlaksanaan pembelajaran dengan menggunakan media power point berbasis humor.

\section{Teknik Analisa Data}

Analisa data yang diperoleh dalam penelitian ini dikelompokan menjadi tiga, yaitu analisa kevalidan, analisa kepraktisan dan analisa keefektifan, akan tetapi dalam penelitian ini analisis kepraktisan dan keefektifan belum dilaksanakan. Analisis data mengacu kepada Nurdin (2007)

\section{HASIL DAN PEMBAHASAN}

Media pembelajaran Biologi berbasis humor telah dikembangkan sesuai dengan langkah-langkah pengembangan yang terdiri atas tahap define, design, dan develop. Adapun hasil yang diperoleh sebagai berikut.

\section{Tahap Pendefinisian (Define)}

\section{Analisis Awal-Akhir}

Berdasarkan kajian peneliti dari berbagai literatur diketahui bahwa belajar akan efektif jika peserta didik dalam keadaan gembira. Salahsatu strategi pembelajaran yang dapat mendukung terciptanya pembelajaran yang efektif adalah strategi pembelajaran menyenangkan berbasis humor. Humor dalam pembelajaran dapat dilakukan guru dengan menggunakan sisipan kata-kata, bahasa, gambar, anekdot, cerita singkat, kartun, karikatur, peristiwa sosial, pengalaman hidup, lelucon atau plesetan yang dapat merangsang terciptanya suasana riang, rileks dan menyenangkan dalam pembelajaran yang mampu menggelitik siswa untuk tertawa. Bukan berbentuk lawakan yang terkadang menyangkut pribadi seseorang, politik, sara, seks dan pornografi yang kurang bermanfaat (Darmansyah. 2010). 


\section{Analisis Siswa}

Analisis siswa ini dilakukan untuk mengetahui karakteristik peserta didik yang sesuai dengan rancangan dan pengembangan media pembelajaran Biologi. Subjek penelitian adalah Siswa kelas XII IPA SMAN 11 Makasar tahun 2015/2016. Pada analisis siswa ini, peneliti menelaah tentang latar belakang pengetahuan siswa dan tingkat perkembangan kognitif serta minat siswa terhadap materi genetika khususnya jika dibelajarkan dengan strategi yang menyenangkan. Hasil telaah menunjukkan bahwa pada tahun berikutnya siswa tersebut akan mempelajari materi-materi Genetika pada tahun ajaran 2015/2016 yang meliputi (1) Pendahuluan dengan pokok-pokok materi genetik, DNA, RNA dan proses sintesis protein (2) Struktur dan Fungsi gen, DNA, kromosom dan sintesis protein (3) pola pewarisan Mendel (4) Hukum segregasi dan pemisahan secara bebas (5) serta penyimpangan semu pada hukum Mendel. Peneliti telah mengumpulkan data mengenai minat siswa kelas XI SMAN 11 Makassar tahun ajaran 2014/2015 terhadap strategi pembelajaran humor, dan diperoleh data bahwa $81,75 \%$ siswa yang memiliki minat yang tinggi terhadap strategi humor, hanya 9, 25\% saja yang kurang berminat dan dari 54 orang siswa, 33 orang diantaranya lebih memilih strategi pembelajaran humor untuk diterapkan dalam pembelajaran daripada strategi pembelajaran lainnya.

\section{Analisis Konsep}

Kegiatan ini dilakukan untuk mengidentifikasi, merinci dan menyusun secara sistematis materi-materi utama yang dipelajari oleh siswa. Materi pembelajaran yang dikembangkan dalam perancangan draft awal perangkat pembelajaran adalah materi yang terkait dengan materi genetik dan pola pewarisan sifat. Untuk materi mitosis dan miosis tidak dikembangkan karena materi tersebut dapat juga diperoleh pada materi reproduksi sel yang berada pada materi kelas XI SMA. Sedangkan materi Pautan dan Pindah silang akan dikembangkan pada penelitian selanjutnya. Hasil analisis konsep materi yang dikembangkan dapat dilihat pada Gambar 1.

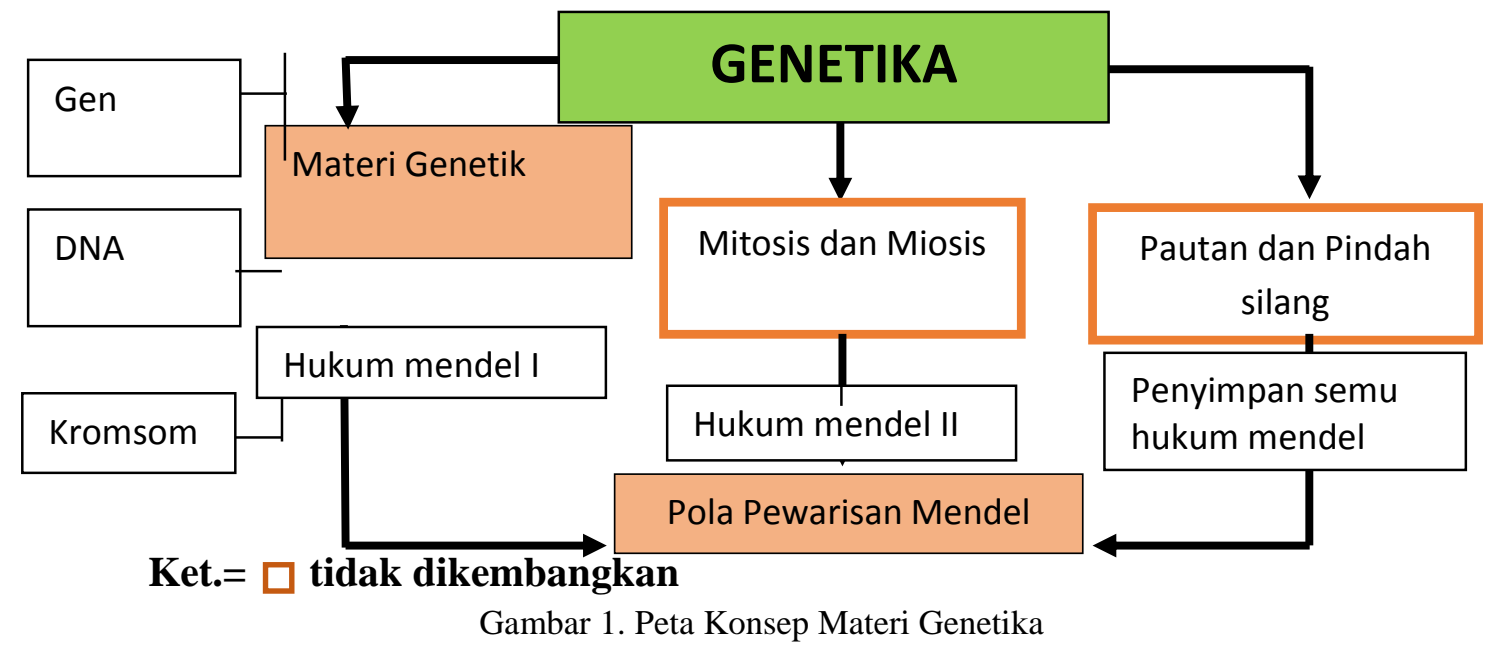

BIOLOGI SEL (VOL 5 NO 2 EDISI JUL-DES 2016 ISSN 2252-858X/E-ISSN 2541-1225) PAGE 116 


\section{Spesifikasi dari Tujuan Pembelajaran}

Kegiatan yang dilakukan pada spesifikasi tujuan pembelajaran adalah merumuskan tujuan-tujuan pembelajaran yang sesuai dengan analisis kurikulum yang telah dilakukan khusus pada standar kompetensi. Perincian tujuan pembelajaran digunakan sebagai acuan dalam merancang draft awal media pembelajaran. Hasil rumusan tujuan pembelajaran tersebut dapat dilihat pada Tabel .1.

Tabel 1. Komponen Tujuan Pembelajaran

\begin{tabular}{|c|c|c|c|}
\hline No & Kompetensi Dasar & Materi Pokok & Tujuan Pembelajaran \\
\hline 1 & $\begin{array}{l}\text { 3.3 Menganalisis } \\
\text { keterkaitan antara } \\
\text { struktur dan fungsi } \\
\text { gen, DNA, } \\
\text { kromosom dalam } \\
\text { proses penurunan } \\
\text { sifat pada mahluk } \\
\text { hidup serta } \\
\text { menerapkan prinsi- } \\
\text { prinsip pewarisan } \\
\text { sifat dalam } \\
\text { kehidupan }\end{array}$ & $\begin{array}{l}\text { Materi Genetik } \\
\text { - Gen } \\
\text { - Kromosom } \\
\text { - DNA } \\
\text { - RNA }\end{array}$ & $\begin{array}{l}\text { 1. Mendefinisikan mengenai gen, } \\
\text { kromosom dan DNA } \\
\text { 2. Menjelaskan hubungan gen, kromosom } \\
\text { dan DNA } \\
\text { 3. Menjelaskan fungsi gen, kromosom dan } \\
\text { DNA } \\
\text { 4. Mendeskripiskan struktur penyusun dari } \\
\text { kromosom } \\
\text { 5. Mendeskripiskan struktur penyusun dari } \\
\text { DNA } \\
\text { 6. Mendeskripiskan struktur penyusun dari } \\
\text { Gen } \\
\text { 7. Mendeskripiskan struktur penyusun } \\
\text { RNA } \\
\text { 9. Menjelaskan fungsi RNA } \\
\text { 10. Menjelaskan jenis-jenis DNA }\end{array}$ \\
\hline 2 & $\begin{array}{l}\text { 3.5 Pola Pewarisan Sifat } \\
\text { pada Hukum Mendel }\end{array}$ & $\begin{array}{l}\text { Hukum Mendel } \\
\text { dan } \\
\text { penyimpangan } \\
\text { semu Hukum } \\
\text { Mendel } \\
\text { - Permasalahan } \\
\text { Interaksi } \\
\text { - Kripstomeri } \\
\text { - Epistasis- } \\
\text { hipostatis } \\
\text { - Komplementer } \\
\text { - Polimeri }\end{array}$ & $\begin{array}{l}\text { 1. Mendefinisikan bunyi hukum mendel I } \\
\text { 2. Mendefinisikan istilah-istilah yang biasa } \\
\text { digunakan dalam persilangan } \\
\text { 3. Menganalisis variasi dalam persilangan } \\
\text { 4. Menentukan ratio genotip dan fenitop } \\
\text { dari persilangan monohibrid } \\
\text { 5. Menunjukkan macam-macam } \\
\text { kemungkinan yang dihasilkan dari } \\
\text { persilangan } \\
\text { 6. Mendefiniskan bunyi hukum mendel II } \\
\text { 7. Menentukan ratio genotip dan fenitop } \\
\text { dari persilangan dihibrid dan polihibrid } \\
\text { 8. Menunjukkan bentuk penyimpangan } \\
\text { Hukum Mendel } \\
\text { 9. Menentukan perbandingan ratio genotip } \\
\text { dan fenitop dari persilangan Intermediet } \\
\text { 10. Menentukan perbandingan ratio genotip } \\
\text { dan fenitop dari kodominan }\end{array}$ \\
\hline
\end{tabular}




\begin{tabular}{|l|l|l|}
\hline & $\begin{array}{l}\text { 11. Menentukan perbandingan ratio genotip } \\
\text { dan fenitop dari atavisme }\end{array}$ \\
& $\begin{array}{l}\text { 12. } \begin{array}{l}\text { Menentukan perbandingan ratio genotip } \\
\text { dan fenitop dari Epistasis-Hipostatis }\end{array} \\
\text { 13. Menentukan perbandingan ratio genotip } \\
\text { dan fenitop dari Gen Komplementer } \\
\text { 14. Menentukan perbandingan ratio genotip } \\
\text { dan fenitop dari Kriptomeri }\end{array}$ \\
\end{tabular}

\section{Tahap Perancangan (Design)}

Tahap ini meliputi perancangan media pembelajaran yaitu perancangan media pembelajaran berupa media presentasi power poin. Media ini terdiri dari beberapa komponen yang memiliki tujuan tertentu, seperti yang dapat dilihat pada Tabel 2

Tabel. 2. Komponen Media Presentasi PPT

\begin{tabular}{|c|l|l|}
\hline No & \multicolumn{1}{|c|}{ Komponen } & \multicolumn{1}{c|}{ Deskripsi } \\
\hline 1 & \multicolumn{1}{|c|}{ Pembuka } & Slide yang membantu guru dalam melakukan Apersepsi \\
\hline 2 & Tujuan Pembelajaran & $\begin{array}{l}\text { Proses dan hasil belajar yang diharapkan dicapai oleh siswa } \\
\text { sesuai dengan kompetensi dasar mata pelajaran Biologi }\end{array}$ \\
\hline 3 & Peta Konsep Materi & Peta cakupan Materi \\
\hline 4 & Batang Tubuh & $\begin{array}{l}\text { Berisi materi pembelajaran yang terdiri atas enam kali } \\
\text { pertemuan }\end{array}$ \\
\hline 5 & Penutup & Penutup \\
\hline
\end{tabular}

\section{Tahap Pengembangan (Develop)}

Tahap pengembangan merupakan tahap penyusunan draft awal media pembelajaran berdasarkan format yang telah dirancang sebelumnnya. Tahap ini meliputi penyusunan draft awal rencana pelaksanaan pembelajaran dengan strategi pembelajaran menyenangkan berbasis humor penyusunan draft awal materi pembelajaran yang dituangkan dalam media power point. Draft awal yang telah disusun kemudian divalidasi oleh validator ahli yang memberikan penilaian terhadap media dan instrumen penelitian. Penilaian validator kemudian dianalisis untuk mengetahui validitas media dan instrumen tersebut. selain itu, validator juga memberikan saran perbaikan terhadap media dan instrumen penelitian tersebut. Saran perbaikan bertujuan untuk menghasilkan produk media pembelajaran dan instrumen penelitian yang layak untuk diimplementasikan di sekolah.

\section{Analisis Data Kevalidan}

Analisis kevalidan media power point didapatkan dari hasil validasi validator melalui lembar penilaian. Adapun hasil analisis data validasi tersebut dapat dilihat pada Tabel 3. 
Tabel 3. Nilai Rata-Rata Hasil Validasi Penilaian Media Power Point

\begin{tabular}{|c|c|c|c|c|c|c|}
\hline \multirow[b]{2}{*}{ No } & \multirow{2}{*}{ Aspek yang Dinilai } & \multicolumn{3}{|c|}{ Penilaian } & \multirow{2}{*}{$\bar{X}$} & \multirow{2}{*}{ Ket } \\
\hline & & $\mathbf{I}$ & II & III & & \\
\hline 1 & Kualitas tampilan & 4,5 & 4,5 & 4,5 & 4,5 & Valid \\
\hline 2 & Penyajian materi & 4 & 4 & 4 & 4 & Valid \\
\hline 3 & $\begin{array}{l}\text { Aspek desain pembelajaran dan komunikasi } \\
\text { visual }\end{array}$ & 4 & 4 & 4 & 4 & Valid \\
\hline \multicolumn{5}{|c|}{ Rata-rata total } & 4,1 & Valid \\
\hline
\end{tabular}

\section{Hasil Revisi}

Hasil validasi menunjukkan bahwa rata-rata seluruh indikator penilaian termasuk pada kategori valid, namun demikian masih ada perbaikan atas saran dari validator. Proses revisi bertujuan untuk menghasilkan media pembelajaran yang lebih berkualitas dan layak digunakan. Hasil validasi menunjukkan kecenderungan yang sama pada keenam power point yang divalidasi. Bagian-bagian draft awal media presentasi PPT yang direvisi dapat dilihat pada Tabel 4.

Tabel. 4. Revisi Media Presentasi PPT

\begin{tabular}{|c|c|c|c|}
\hline $\begin{array}{c}\text { Standar } \\
\text { Kompetensi }\end{array}$ & Materi & Saran Perbaikan & Ket \\
\hline $\begin{array}{l}\text { 3.3 Menganalisis } \\
\text { keterkaitan antara } \\
\text { struktur dan fungsi } \\
\text { gen, DNA, } \\
\text { kromosom dalam } \\
\text { proses penurunan } \\
\text { sifat pada mahluk } \\
\text { hidup serta } \\
\text { menerapkan prinsi- } \\
\text { prinsip pewarisan } \\
\text { sifat dalam } \\
\text { kehidupan }\end{array}$ & $\begin{array}{l}\text { Materi Genetik } \\
\text { - Gen } \\
\text { - Kromosom } \\
\text { - DNA } \\
\text { - RNA }\end{array}$ & 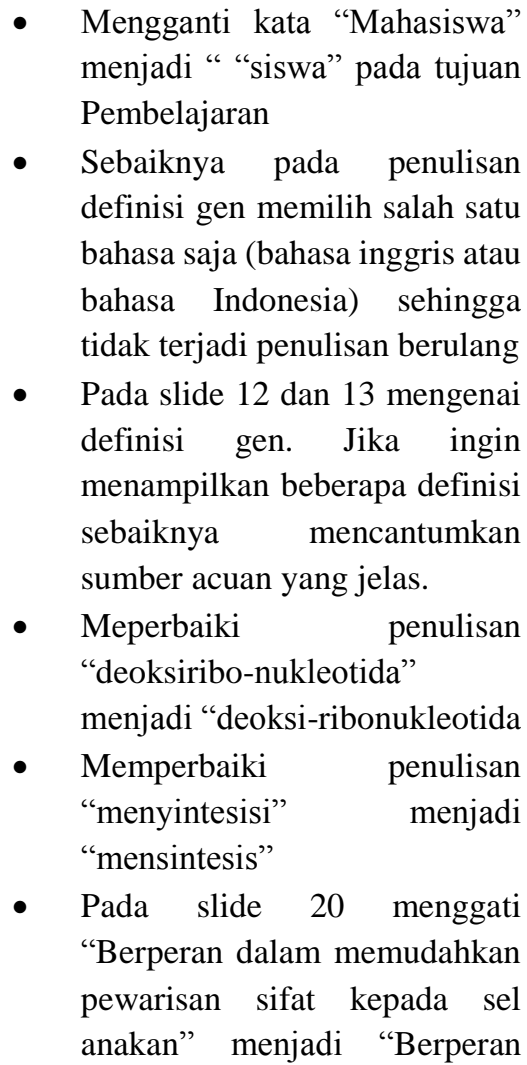 & \\
\hline
\end{tabular}




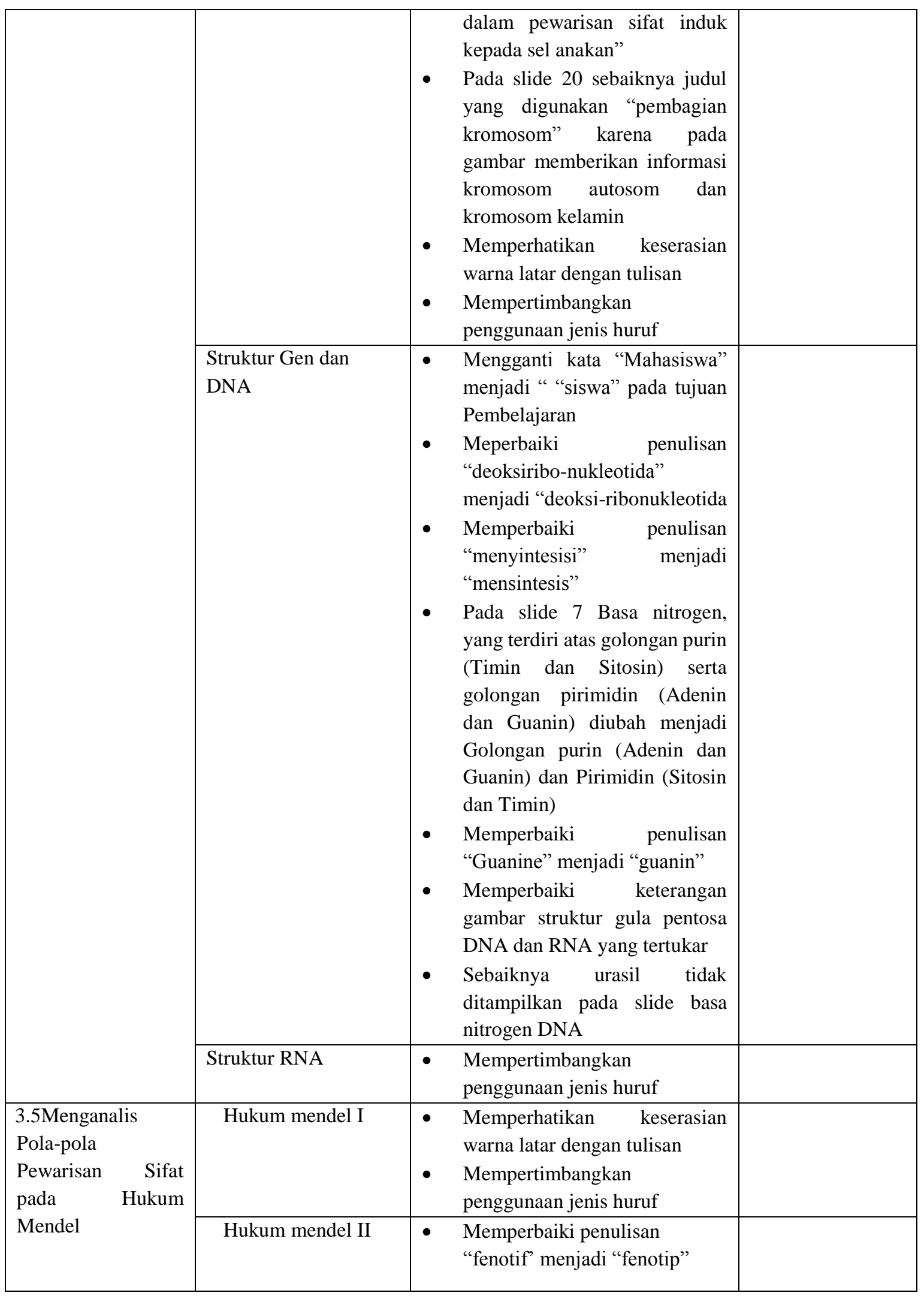




\begin{tabular}{|l|l|l|l|}
\hline & $\begin{array}{l}\text { Penyimpangan semu } \\
\text { hukum mendel }\end{array}$ & $\begin{array}{l}\text { Memperbaiki penulisan } \\
\text { "fenotif" menjadi "fenotip } \\
\text { Memperbaiki penulisan " } \\
\text { epistasi" menjadi "epsistasis" }\end{array}$ & \\
\hline
\end{tabular}

Hasil revisi dapat dicontohkan sebagai berikut.

1. Analisis Kevalidan media pembelajaran
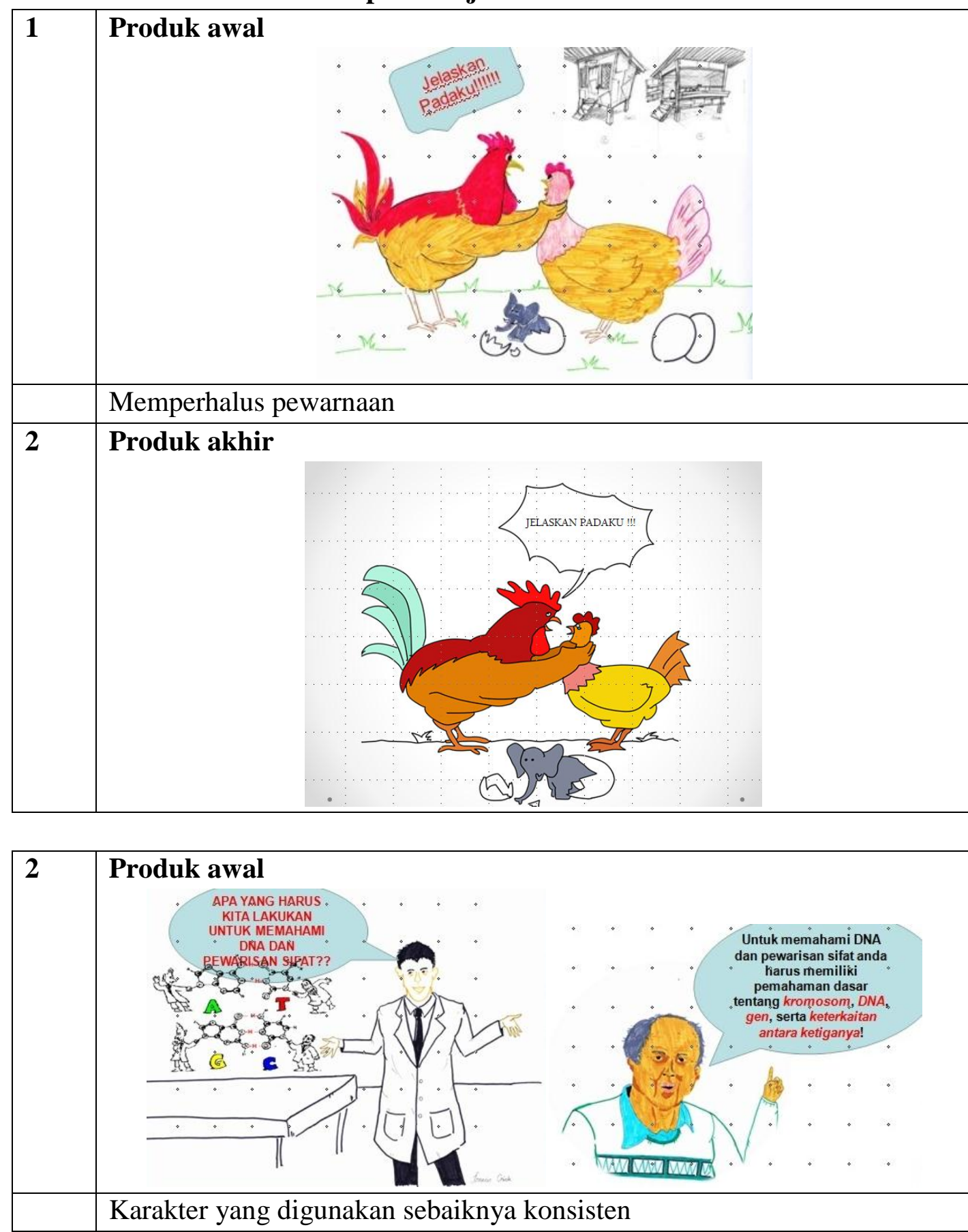

BIOLOGI SEL (YOL 5 NO 2 EDISI JUL-DES 2016 ISSN 2252-858X/E-ISSN 2541-1225) PAAE 121 

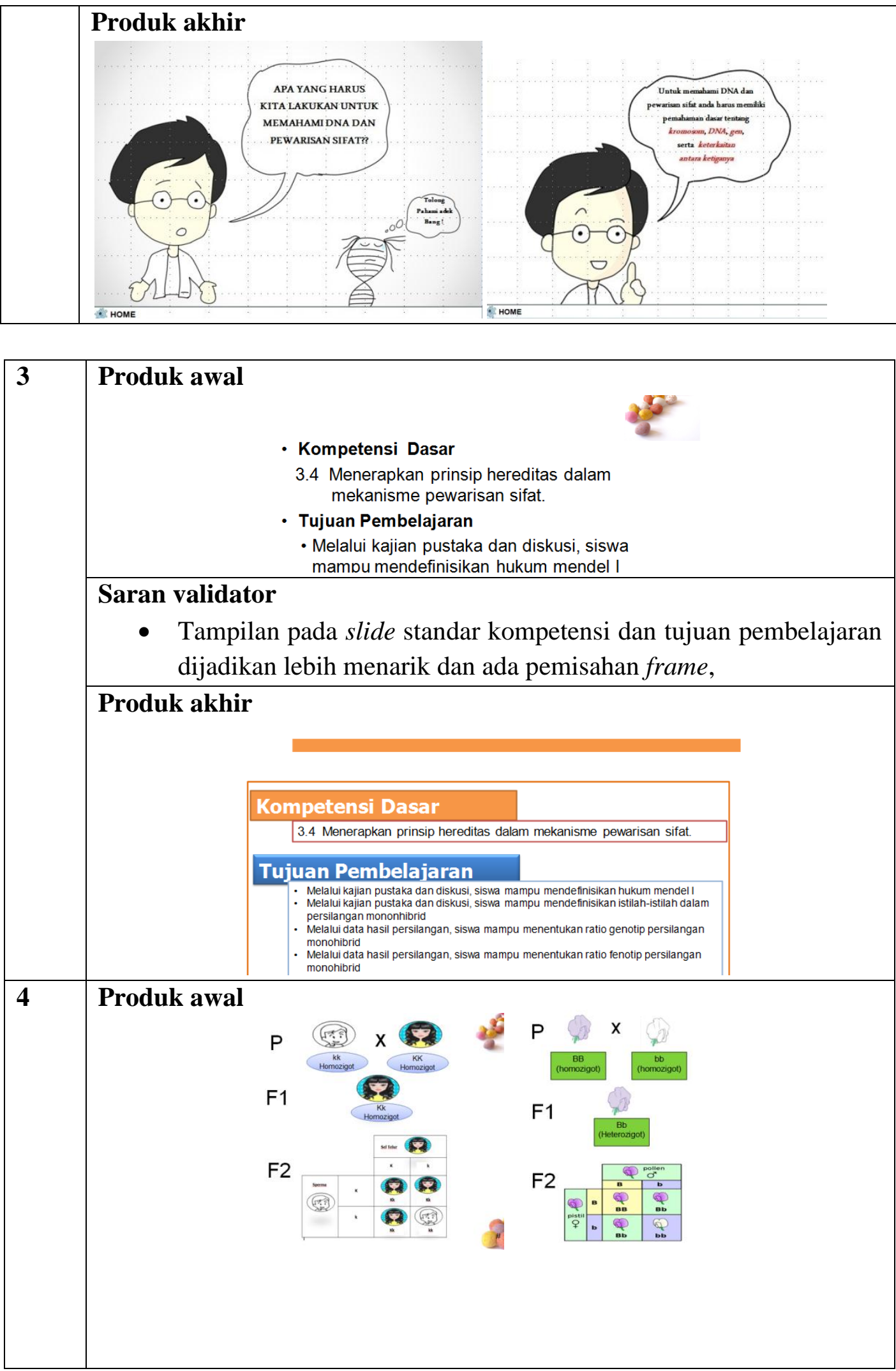

BIOLOGI SEL (VOL 5 NO 2 EDISI JUL-DES 2016 ISSN 2252-858X/E-ISSN 2541-1225) PAGE 122 


\begin{tabular}{|c|c|}
\hline Saran perbaikan \\
- \\
Gambar kartun pada papan catur mengenai persilangan rambut \\
keriting dan rambut lurus sebaiknya diperbaiki agar tidak terkesan \\
"terpaut sex" \\
- \\
Sebaiknya warna gambar pada persilangan bunga warna ungu dan \\
bunga warna putih tetap sama, agar tidak terkesan persilangan \\
bunga warna ungu dan warna putih bersifat intermediet.
\end{tabular}

Rata-rata total nilai kevalidan media presentasi powerpoint yang dikembangkan pada penelitian adalah 4,1 . Hasil validasi menunjukkan bahwa media presentasi powerpoint dinyatakan valid. Saran perbaikan media presentasi powerpoint antara lain mempertimbangkan penambahan keterangan gambar, menghindari penggunaan warna dan animasi yang terlalu banyak dalam satu slide, karena dapat mengganggu penyampaian materi. Penggunaan template sendiri untuk meningkatkan daya tarik presentasi dan memperjelas pesan yang akan disampaikan. Saran lainnya yaitu mengganti jenis huruf tipe harrington pada beberapa slide karena jenis huruf ini sulit terbaca. Pemilihan huruf font merupakan salah satu faktor penentu tersampainya pesan dalam sebuah slide. Menurut Don MacMillan pemilihan jenis huruf dilakukan secara berhatihati, jenis huruf yang memiliki banyak lengkungan akan lebih mudah mempengaruhi audiens dalam hal ini siswa karena huruf ini memiliki kesan dekat dan bersahabat.

Penggunaan template sendiri dan relatif konsisten dapat meningkatkan daya tarik media dan memperjelas apa yang disampaikan. Kevalidan dapat juga dilihat dari penilian validator yang keseluruhan menyatakan valid karena media presentasi yang dikembangkan telah memenuhi syarat-syarat penyusunan media dengan baik diantaranya penyajian materi pelajaran dengan uraian yang lengkap, pengorganisasian materi secara sistematis dan menggunakan kaidah bahasa yang baku.

\section{KESIMPULAN}

Perangkat media pembelajaran berbasis humor dikembangkan dengan menggunakan model pengembangan perangkat 4-D yang dikembangkan oleh $\mathrm{S}$. Thagarajan, Dorothy S. Semmel, dan Melvyn I. Semmel yang terdiri atas 4 tahap utama yaitu: Define (Pembatasan), Design (Perancangan), Develop (Pengembangan) dan Disseminate (Penyebaran), sedangkan tahapan Disseminate (Penyebaran) belum dilaksanakan. Media power point yang dikembangkan telah memenuhi kriteria valid.

\section{SARAN}

Perlu adanya uji coba produk dalam skala besar untuk melihat pengaruh produk hasil pengembangan terhadap hasil belajar cognitif siswa, khususnya pada konsep yang berhubungan dengan genetika 


\section{DAFTAR PUSTAKA}

Darmadi, Hamid. 2011. Metode Penelitian Pendidikan. Alfabeta. Bandung.

Darmansyah. 2010. Strategi Pembelajaran Menyenangkan dengan Humor. Bumi Aksara. Jakarta.

Deiter, Ron. 2000. The Use of Humor as a Teaching Tool in the College Classroom. NACTA Journal, June (Page 22-23).

Kenny, D.A. 1975. A Quasi-Experimental Approach to Assessing Treatment Effects in the Non equivalent Control Group Design. Physiological Bulletin. Vol.82, No.3, 345-362. Harvard University

Ketabi, Saeed dan Shahla S. 2009. Investigating Persian EFL Teachers and Learner's Attitude Toward Humor in Class. University of Isfahan, Iran. International Journal of language Studies (IJLS), Vol.3 (4), (page 435-452).

McGrath, 2013. Hcott. Humor in the Classroom. www.usma.edu/cfe/Literature/McGrath_13.pdf. Makassar. Diakses 18 Februari 2015.

Nurdin. 2007. Model Pembelajaran Matematika yang Menumbuhkan Kemampuan Metakognitif Untuk Menguasai Perangkat Pembelajaran. Disertasi. Tidak diterbitkan. Surabaya: PPs Universitas Negeri Surabaya.

Reville, William. 2004. The Biological Basis of Humor. University College. Cork.

Shiyab, Said. 2008. Pedagogical Effect of Humor on Teaching. United Arab Emirates University.

Thiagarajan, S., \& Semmel, M.I. 1974. Instructional Development for Training Teachers of Exceptional Children. Minneapolish, Minnesota: Leadership Training Institute/Special Education. University of Minnesota.

Wanzer, M. 2002. Use of Humor in the Classroom: The good, the bad, and the not-sofunny things teachers say and do. In C. \&. McCroskey, Communication for Teachers (pp. 116-125). Boston: Allyn \& Bacon. 